\title{
Risk Control in the Investment Strategy as a Factor of Improving the Effectiveness of the Mining Enterprise
}

\author{
Pavel Kryukov ${ }^{1}$, and Valentina Kryukova ${ }^{2, *}$ \\ ${ }^{1}$ Branch No. 11 PJSC "MOSOBLBANK", 650000, 24 Vesennyaya st., Kemerovo, Russia \\ ${ }^{2}$ T.F. Gorbachev Kuzbass State Technical University, Department of Applied Information \\ Technologies, 650000, 28 Vesennyaya st., Kemerovo, Russia
}

\begin{abstract}
The article examines the method of situational risk control of the investment operation in financial markets. The method is based on the proposed indicator - the loss cover ratio, which is expressed in terms of coefficients - the risks of opening and closing the investment position. The known methods and indicators of risk control are considered; the differences and advantages of the author's method are shown. It was empirically established that the use of the proposed method of situational control in the investment strategy allowed increasing profitability by $32 \%$ due to a significant reduction in the number of loss transactions. Risk control in the investment strategy contributes to increasing efficiency in ensuring stable financial position of the enterprise.
\end{abstract}

\section{Introduction}

The investment activity of a mining enterprise has two aspects.

The successful operation of the enterprise in the long term and its profitability depend on the decisions made by the financial managers. Important decisions affecting the stability of the company's financial position are investment decisions.

Exporting industries of the fuel and raw materials complex, which include mining production, are able to develop independently on the basis of self-financing the priority activities, including investments in financial markets (money market, loan and securities market).

Enterprises independently or through brokers carry out various investment operations in the currency and stock markets to diversify the assets portfolio management. They also realize conversion and loan-and-deposit operations with foreign currency, as well as algorithmic exchange trade of financial instruments (for example, futures contracts) for foreign currency, securities and commodities.

Another area of enterprises' activity in the field of financial management is insurance of currency, credit and interest risks. Mining enterprises that supply their products abroad are exposed to the risk of changing the price for coal products (currency risk) in foreign markets. The foreign exchange market has high liquidity from the perspective of investment

*Corresponding author: kvv.vt@kuzstu.ru 
activity. The interest of enterprises to it is explained by the necessity of currency exchange, as well as insurance of risks.

The purpose of the study is to perform the analysis of the current investment risk control indicators used in foreign and Russian investment practice in the foreign exchange and stock markets, to offer the method of situational risk control that differs from the known by controlling the ratio of excess/shortage of cash inflow over its outflow in time in the investment process.

\section{Results and discussion}

There is not much information about the use of the current risk control indicators in the investment strategy in scientific literature. The systematization of indicators and their evaluation are given in Table 1.

The author's indicator of the loss cover ratio differs from the known by the mechanism of assessing the effectiveness of current trade. The relative indicator takes into account: the current undistributed profit/loss of the open position; the part of own accumulated capital potential loss (risk of closing); accumulated in time profit and loss of closed positions separately, and on the whole shows the current coverage of $1 \%$ loss of the investment (trade) transaction by time $\mathrm{t}$.

Known indicators (Ch. LeBeau and D.W. Lucas [1], J.O.Katz, D.L. McCormick [2]) estimate only undistributed profit/loss and do not take into account the size of the investor's account (assets), the value of which varies in time.

The limit risk indicator of S. Bhojraj, R.J. Bloomfield, W.B. Tayler [3] is the ratio of net profit/loss.

The risk indicator of M. Mazumder, Edward M. Miller, Oskar A. Varela [4] is expressed through regression models that reflect the correlations of the fund's portfolio and the market index, which requires a revision of the coefficients of the regression equations due to structural market changes over time.

Table 1. Indicators of current risk control in the investment strategy.

\begin{tabular}{|c|c|c|}
\hline Indicator & Author & Distinctive features \\
\hline $\begin{array}{l}\text { Limit risk } \mathrm{R}=\mathrm{S} / \mathrm{A} \text {, where } \mathrm{S} \text { - equity, excess assets } \\
\text { on liabilities; } \mathrm{A} \text { - assets, defined as cash funds plus } \\
\text { the current market value of any trader's shares. } \\
\text { Liabilities are defined as debt plus the current } \\
\text { market value of any shares sold cheaply. }\end{array}$ & $\begin{array}{l}\text { S. Bhojraj, R.J. } \\
\text { Bloomfield, } \\
\text { W.B. Tayler [3] }\end{array}$ & $\begin{array}{l}\text { The limit risk indicator is } \\
\text { proposed for the stock } \\
\text { market, can be adapted for } \\
\text { the foreign exchange market. }\end{array}$ \\
\hline $\begin{array}{l}\text { In the investment strategy limiting the risk - no } \\
\text { more than } 30 \% \text { of the value of investor's account; } \\
\text { follow-up stop of risk (stop); risk - } 1.5 \% \text { of the } \\
\text { account value in one transaction. }\end{array}$ & $\begin{array}{l}\text { Ch. LeBeau, D. } \\
\text { W. Lucas [1] }\end{array}$ & $\begin{array}{l}\text { Absolute risk values are used, } \\
\text { which does not always } \\
\text { correspond to constantly } \\
\text { changing market conditions. }\end{array}$ \\
\hline $\begin{array}{l}\text { Modified standard exit strategy with additional } \\
\text { rules based on the ATR }(50) \text { indicator: a limit } \\
\text { order to close the position when reaching } \\
1.5 \times \text { ATR }(50) \text { below the opening price; profit } \\
\text { target }-4,5 \times \text { ATR }(50) \text { above the opening price } \\
\text { when buying, for selling }- \text { on the contrary }\end{array}$ & $\begin{array}{l}\text { J.O. Katz, D.L. } \\
\text { McCormick [2] }\end{array}$ & $\begin{array}{l}\text { Absolute values of the } \\
\text { indicator coefficients are } \\
\text { used, which does not always } \\
\text { correspond to the current } \\
\text { (constantly changing) market } \\
\text { conditions and leads to a } \\
\text { small number of transactions }\end{array}$ \\
\hline $\begin{array}{l}\text { Sales strategy "day of the week", based on the } \\
\text { serial correlation: input/output based on the } \\
\text { current value of the fund's return (Rt), the risk of } \\
\text { "market time" }(\gamma) \text { and analysis of the serial } \\
\text { correlation of the fund's portfolio and the market } \\
\text { index (separately): Rt }=0,8237 \times R f, t \text {, where Rf,t }\end{array}$ & $\begin{array}{l}\text { M. Mazumder, } \\
\text { Edward M. } \\
\text { Miller, Oskar A. } \\
\text { Varela [4] }\end{array}$ & $\begin{array}{l}\text { The risk indicator is } \\
\text { expressed through regression } \\
\text { models that reflect the } \\
\text { correlations of the fund's } \\
\text { portfolio and the market } \\
\text { index, which requires a }\end{array}$ \\
\hline
\end{tabular}




\begin{tabular}{|c|c|c|}
\hline $\begin{array}{l}\text { - index profitability in a day } \mathrm{t} ;(\mathrm{Rp}-\mathrm{Rf})=\alpha+\beta \\
(\mathrm{Rm}-\mathrm{Rf})+\gamma(\mathrm{Rm}-\mathrm{Rf})^{2}, \quad \text { where }(\mathrm{Rp}-\mathrm{Rf}) \text { is the } \\
\text { portfolio excess; }(\mathrm{Rm}-\mathrm{Rf})-\text { excess of the asset } \\
\text { market (shares); } \alpha=\text { selective risk; } \beta=\text { systematic } \\
\text { risk; } \gamma=\text { risk of "market time" }\end{array}$ & & $\begin{array}{l}\text { revision of the coefficients of } \\
\text { the regression equations due } \\
\text { to structural market changes } \\
\text { over time. }\end{array}$ \\
\hline $\begin{array}{l}\text { The strategy "trading in equity spreads" describes } \\
\text { the simultaneous trading of two assets in the stock } \\
\text { and exchange markets (selling one and buying the } \\
\text { other): G is the probability distribution function } \\
\text { of the FRE asset (the Cauchy function); F (Fnm) } \\
=\mathrm{u} \text { is the probability distribution function of the } \\
\text { FNM asset (Laplace function); } \mathrm{H}(\mathrm{x}, \mathrm{y}) \text { is the form } \\
\text { of the joint distribution function with the limits } \mathrm{F} \\
\text { and G and the connection C; C(u, v) - a } \\
\text { connection of probability distribution of the } \\
\text { traded asset pair. }\end{array}$ & $\begin{array}{l}\text { By Luan } \\
\text { Ferreira [5] }\end{array}$ & $\begin{array}{l}\text { Connection determines the } \\
\text { management of trading } \\
\text { positions and capital. It } \\
\text { requires specification of } \\
\text { trading rules, specification of } \\
\text { models for other markets } \\
\text { (assets) }\end{array}$ \\
\hline $\begin{array}{l}k_{t}=\frac{\sum_{t} N P+N / P_{t}^{+}+n o \times A k k}{\sum_{t} N Y+N / P_{t}^{-}} \\
\begin{array}{l}\text { If } k_{t} \leq 1 \text { or if there is a "close position" signal, the } \\
\text { order is immediately deleted }\end{array}\end{array}$ & P.A. Kryukov & $\begin{array}{l}\text { Accumulated and } \\
\text { undistributed profit/loss by } \\
\text { the time } t \text { is dynamically } \\
\text { estimated separately. The } \\
\text { ratio of indicators the } \\
\text { amount of the account and } \\
\text { the initial value of Depo by } \\
\text { the time the order is placed } \\
\text { is taken into account }\end{array}$ \\
\hline
\end{tabular}

In order to carry out current monitoring and risk management in the investment process, a method of situational risk control of an investment (trade) operation is proposed. The method of situational risk control takes into account the totality of signals of the mathematical model of the market and the value of the loss cover ratio changing over time: the position is opened if there is a specified (optimal for the particular strategy) part of the initial investment amount and the immediate liquidation of transactions having a current loss availability when there is the corresponding signals of the mathematical model and the value of the dynamic indicator - the loss cover ratio. Let us consider the structure of the indicator and the method of risk management based on it. The dynamic indicator of the loss cover ratio is:

$$
k_{t}=\frac{\sum_{t} N P+N / P_{t}^{+}+n o \times A k k}{\sum_{t} N Y+N / P_{t}^{-}},
$$

where: $t$ - current time, $N P$ - the amount of profits, taking into account previously closed transactions; N/P - the current amount of undistributed profit (sign "+") and loss (sign"-"), no - part of the investor's capital on the account at the moment of opening position $(A k k)$ - potential loss on closing position, $N Y$ - the amount of losses taking into account previously closed transactions. Position management in the investment strategy: $k_{t}$ $>1$ - open order is not closed; $k_{t} \leq 1$ if there is a "close position" model signal, the order is immediately deleted. The opening order is set according to the signal of the mathematical model and if the following condition is met: $A k k \geq n a \times D e p o$

Where $A k k$ - the investor's capital at the time of placing the order; $n a$ - the part of capital - the initial value of Depo deposit (the risk of opening a position).

When managing the position, the ratio of the account amount to the initial value of Depo is also taken into account when the order is placed, which makes it more objective to 
assess the current state of the investor's transaction, because the account amount (balance) is the cumulative financial result of all closed positions and non-trade transactions on the customer's account.

To forecast the market, different mathematical apparatus based on various behavioral properties of the market is used: fractal analysis (Mandelbrot BB [6]), neural networks (AK Dhamija [7], De Groot C [8], Hawley DD [9]), nonlinear stochastic models of autoregressive conditional heteroscedasticity (Bollerslev T. [10, 11], Engle RF [12], Nelson DB [13], Glosten LR et al. [14]), spectral analysis (Childers DG, [15]), etc. The main drawbacks of the known models are pre-forecasting character, low accuracy of the forecast of the trend change moment, delay of signals.

The author's methodical approach to investment includes two developed forecast market models at different time intervals (time-frames), which makes it possible to improve the accuracy of the trend change forecast by cutting off the lateral trend.

1. Model M1 on the hour time-frame. It is probability indicator with cutoff threshold 0.5. The logit-regression model looks like this: $L(x)=6,0+11,1992 \times X_{2}-20,0 \times X_{3}-$ $19,8217 \times X_{1}$,

$$
P(L(x))=\frac{1}{1+e^{-L(x)}},
$$

Adequate assessment: $\chi^{2}(\mathrm{v}) / \mathrm{p}-\chi^{2}(3)=324.9306 / \mathrm{p}=0.00000$; Maxlikelihood 17,4835; The significance level of Wald's statistics $\chi^{2}$ for coefficients is $\mathrm{P}=0.00000 ; 0.05$.

2. FSH model on the day time-frame. The trend indicator based on factor scaling looks like: Faktor $1=x_{4} \times(-0,37513)+x_{5} \times(-0,391583)+x_{6} \times(-0,385691)$,

where: $-19.66 \leq$ Faktor $1 \leq 22.83$ - flat; Faktor $1<-19.66$ is an uptrend; Faktor $1>22.83$ is a downward trend. The percentage of correctly classified cases during verification is 89.46 ; the eigenvalue $\lambda=2.26$; the dispersion share is $75.48 \%$, the reliability factor is $\alpha=0.92$.

Substantial meaning of variables: identification of the trend direction - converted values of linear deviation $\left(\mathrm{x}_{1}\right)$, average increase in the closing price of the instrument $\left(\mathrm{x}_{2}\right)$; identification of the turning point - converted values of oscillator signals $\operatorname{RSI}\left(\mathrm{x}_{3}\right)$; identification of the trend direction - the change rate of the trend, corresponds to the tangent of the slope of the support lines or resistance to the time axis, drawn through adjacent peaks or valleys $\left(\mathrm{x}_{4}, \mathrm{x}_{5}, \mathrm{x}_{6}\right)$.

With the help of models, five investment strategies and five corresponding mechanical trading systems were built as technical investment tools. The distinctive features of strategies are:

a) the formalization of signals "opening/closing" positions based on the signals of two models simultaneously (trading on the trend on the hour time-frame with the flat cutting off on the daily data);

b) the combination of mathematical models separately on different time-frames; implementation of double-choice tactics for entering the market (analysis of different time scales (hour, day) in order to find the optimal entry point); implementation of tactics "signal refinement" based on the coincidence of signals in two models. The goal of all developed strategies is to maximize the profit on the difference in the exchange rates of the EUR/ USD instrument.

All five developed strategies have shown the investment efficiency and suitability. However, the strategy with the tactic of "double choice" in the process of real-time trading on the demo-accounts of the Alpari broker in the interval [09.02.2015 - 17.04.2015] showed the best result $-77 \%$ of annual return. The field of strategy application is a 
currency over-the-counter market, the exchange market - trading in financial instruments. Software for implementation: the MetaTrader5 trading terminal of Alpari broker.

The experiments have been carried out to determine the values of the parameters $n o, n a$ for variants of the strategy which has both profit and loss. The results are shown in Table 2 . The use of restrictive conditions when placing orders together with the indicator of the loss cover ratio at the time of order removal, the search for optimal values of $n o$ and $n a$ led to an increase in trade efficiency (lines 1 and 3,2 and 4). At the same time, the result was obtained - the ratio of profits to losses increased and amounted to: $242.9 \%$ (line 3 ) and $58.5 \%$ (line 4).

Unprofitable trade of the same strategy was studied. Using capital and risk management in a mechanical trading system including proposed by the author $k_{t}$ indicator led to an increase in profitability $(+32 \%)$ and a significant decrease in the total volume of transactions, including transactions with losses (lines 5 and 6, Table 2).

The method of "simple search" with the use of nodal points has been used to search for optimal parameters, aimed at minimizing losses for the strategy under study. It was established that for $n o=0.2(20 \%)$ the loss is minimal ( -275.6 \& US), provided that the accumulated own funds by the time the position is opened are not less than the amount of initial deposit $(n a=1,0)$. Using the coefficient $k_{t}$ proposed by the author with the values $n o=$ 2.0 and $n a=1.0$ led to a decrease in the strategy unprofitability (in 36 times), of 26 unprofitable transactions only 2 remained (Table 2 ).

Table 2. Profitability of transactions with and without using the loss cover ratio in the strategy.

\begin{tabular}{|l|l|l|l|l|l|}
\hline No & \multicolumn{1}{|c|}{ Profit, \$ } & Profitability & \multicolumn{1}{|c|}{$\begin{array}{c}\text { Total/ profitable } \\
\text { transactions }\end{array}$} & \multicolumn{1}{|c|}{ no } & na \\
\hline 1 & $4415,40\left(\right.$ without $\left.\mathrm{k}_{\mathrm{t}}\right)$ & 1,39 & $10 / 3$ & - & - \\
\hline 2 & $9230,80\left(\right.$ without $\left.\mathrm{k}_{\mathrm{t}}\right)$ & 1,60 & $12 / 7$ & - & - \\
\hline 3 & $15140,60\left(\right.$ with $\left.\mathrm{k}_{\mathrm{t}}\right)$ & 1,49 & $12 / 7$ & 0,51 & 0,06 \\
\hline 4 & $14633,80\left(\right.$ with $\left.\mathrm{k}_{\mathrm{t}}\right)$ & 1,91 & $25 / 7$ & 0,69 & 0,26 \\
\hline 5 & $-9944,0\left(\right.$ without $\left.\mathrm{k}_{\mathrm{t}}\right)$ & 0,64 & $26 / 11$ & - & - \\
\hline 6 & $-275,6\left(\right.$ with $\left.\mathrm{k}_{\mathrm{t}}\right)$ & 0,89 & $2 / 1$ & 0,2 & 1,0 \\
\hline
\end{tabular}

\section{Conclusion}

The method of situational risk control of investment (trade) operation was developed. It differs from the known by the current control of the ratio of excess/shortage of cash inflow over its outflow in time. The method takes into account a set of signals of developed mathematical market models at different time and the value of time-varying loss cover ratio.

The index of loss cover ratio which differs from the known by the mechanism of assessment efficiency of current trade was proposed. Accumulated and undistributed profit /losses by time $t$ are dynamically estimated separately. When managing the position, the ratio of the account amount and the initial value of deposit by the moment of opening the position is taken into account, which makes the assessment of the current state of the investor's operation more objective.

An investment strategy with situational risk control can be recommended to mining enterprises for financial investments. 


\section{References}

1. Ch. LeBeau, D. W. Lucas, Computer Analysis of The Futures Market (IRWIN Professional Publishing, Lomdon, 1992)

2. J. O. Katz, D. L. McCormick, The Encyclopedia of Trading Strategies (McGraw-Hill Companies, New York, 2000)

3. S. Bhojraj, R. J. Bloomfield, W. B. Tayler, RFS, 5, 2059 (2009)

4. M. I. Mazumder, E. M. Miller, O. A. Varela, JBFA, 37:7, 979 (2010)

5. B. Ferreira, Futures, 11, 38 (2008)

6. A. K. Dhamija, V.K. Bhalla, Neural Computers \& Applications, 20, 355 (2011)

7. C. De Groot, IPS Research Report, 3, 10038 (1993)

8. D. D. Hawley, J.D. Johnson, D. Raina, Financial Analysts Journal, 12, 63 (1990)

9. T. Bollerslev, Rev. Economics and Statistics, 69, 542 (1987)

10. T. Bollerslev, J. Econometrics, 31, 307 (1986)

11. R. F. Engle, J. Econometrics, 50, 987 (1982)

12. D. B. Nelson, J. Econometrics, 59, 317 (1991)

13. L. R. Glosten, R. Jagannathan, D. Runkle, J. of Finance, 48, 1779 (1993)

14. D. G. Childers, Modern spectrum analysis (IEE Press, New York, 1978) 